DP-1363

662974

\title{
SRP HIGH-LEVEL ALPHA ANALYTICAL FACILITY
}

\author{
M. G. LINN \\ D. P. LILLY
}
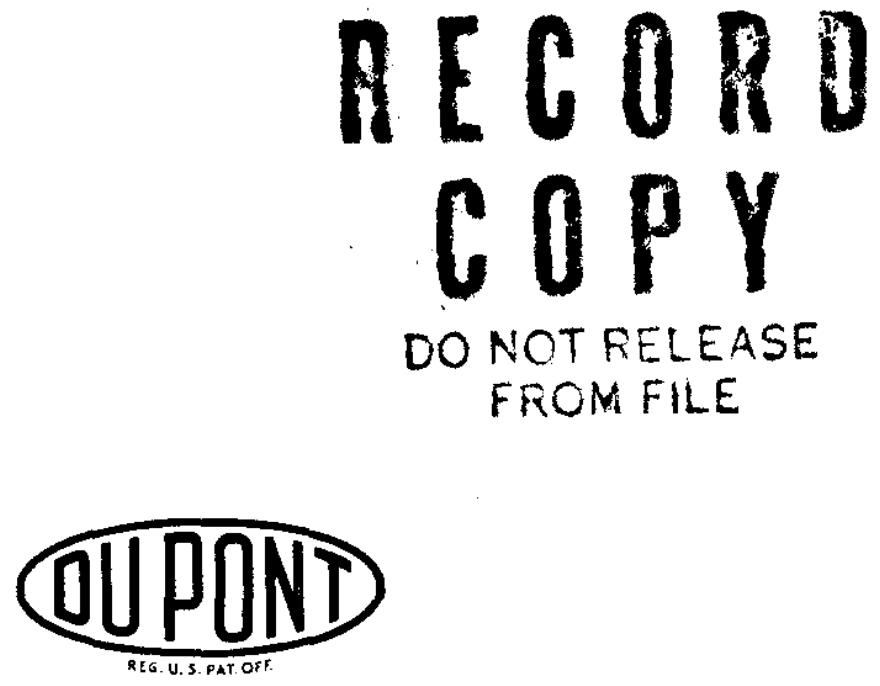

E. I. du Pont de Nemours \& Co.

Savannah River Laboratory

Aiken, S. C. 29801 


\section{NOTICE}

This report wals prepared as an account of work sponsored by the United States Government. Neither the United States nor the United States Atomic Energy Commission, nor any of their employees, nor any of their contractors, subcontractors, or their employees, makes any warranty, express or implied, or assumes any legal liability or responsibility for the accuracy, completeness or usefulness of any information, apparatus, product or process disclosed, or represents that its use would not infringe privately owned rights.

Printed in the United States of America Available from

National Technical Information Service

U. S. Department of Commerce

5285 Port Royal Road

Springfield, Virginia 22151

Price: Printed Copy $\$ 4.00$; Microfiche $\$ 1.45$ 


\title{
SRP HIGH-LEVEL ALPHA ANALYTICAL FACILITY
}

\author{
by \\ M. G. Linn and D. P. Lilly
}
Approved by
W. P. Bebbington, Superintendent
Works Technical Department
and
H. J. Bowman, Superintendent
Projects Department Savannah River Plant

Publication Date: August, 1974
E. I. du Pont de Nemours \& Co.
Savannah River Laboratory
Aiken, S. C. 29801

PREPARED FOR THE U. S. ATOMIC ENERGY COMMISSION UNDER CONTRACT ATI07-2)-1 


\begin{abstract}
A laboratory facilit for the routine analysis of ${ }^{238} \mathrm{Pu}$ oxide was designed and built for the Works Technical Laboratories of the Savannah River Plant. The facility consists of a Dry Oxide Handling Laboratory and a Solution Analysis Laboratory separated by a Service Area. Enclosures for containing radioactive materials are interconnected stainless steel glove boxes, hoods, and radiobenches. Design criteria emphasized personnel safety, environmental protection, and operating efficiency and flexibility. Features of the facility include: effective contamination control; an efficient sample entry, transfer, and exit system; corrosion resistance; automatic fire detection and suppression; and ready access to all services. The entire facility occupies a space of only $24 \times 24 \mathrm{ft}$. Construction required one year and cost $\$ 250,000$.
\end{abstract}




\section{CONTENTS}

\section{Page}

Introduction .................. 5

Contamination and Radiation Control . . . . . 5

Sample Entry, Transfer, and Exit Systems . . . . . 8'

Corrosion Resistance............... 10

Fire Detection and Suppression System. . . . . . 10

Service Access . . . . . . . . . . . . . . . 11

Cost............................. 11 


\section{LIST OF FIGURES}

Figure

Page

1. SRP High-Level Alpha Analytical Facility. . . . . . 6

2. Solution Analysis Laboratory (looking North) . . . . 7

3. Solution Analysis Laboratory (looking South) . . . . 7

4. Typical Glove Box . . . . . . . . . . . . . 9

5. Isolation Box (Transfer Air Lock) - Hood 1. . . . . 9

6. Gravity-Powered Trolley .............. 11

7. Service Area (looking South)........... . 12

8. Service Area (looking North).......... . 12 


\section{SRP HIGH-LEVEL ALPHA ANALYTICAL FACILITY}

\section{INTRODUCTION}

Specification analyses of ${ }^{238} \mathrm{Pu}$ oxide are routinely made by the Works Technical Laboratories of the Savannah River Plant (SRP). A facility formerly used for these analyses had severely deteriorated from radiation damage and corrosion. A new facility was proposed, designed, and built as a replacement.

The new facility, consisting of 55 linear feet of hoods, glove boxes, and radiobenches, was designed to fit into the previously used $24 \mathrm{ft} \times 24 \mathrm{ft}$ space (Figures 1, 2, and 3). Primary goals in the design included personnel safety, environmental protection, operating efficiency, and flexibility for adaptation to future needs. Operating experience during the past year has confirmed that these goals have been met. Features of the new facility include the following:

- Better contamination control.

- A more efficient sample entry, transfer, and exit system.

- Increased corrosion resistance.

- Automatic fire detection and suppression.

- Improved access to all services.

\section{CONTAMINATION AND RADIATION CONTROL}

The facility provides continuous containment during transfers between glove boxes. Additional contamination control is attained by using hoods and radiobenches to house all normal glove box access ports and by providing a complete operating area air change every one to two minutes.

Glove box exhaust air is filtered through three high efficiency particulate air (HEPA) filters in series and finally through a sand filter before discharge to the environment. A11 glove box inlet filters and gloves are cartridge-mounted and can be changed without breaking containment (Figure 4). Used gloves and inlet and outlet filters are removed from the glove box train through bag ports in hoods and radiobenches. 


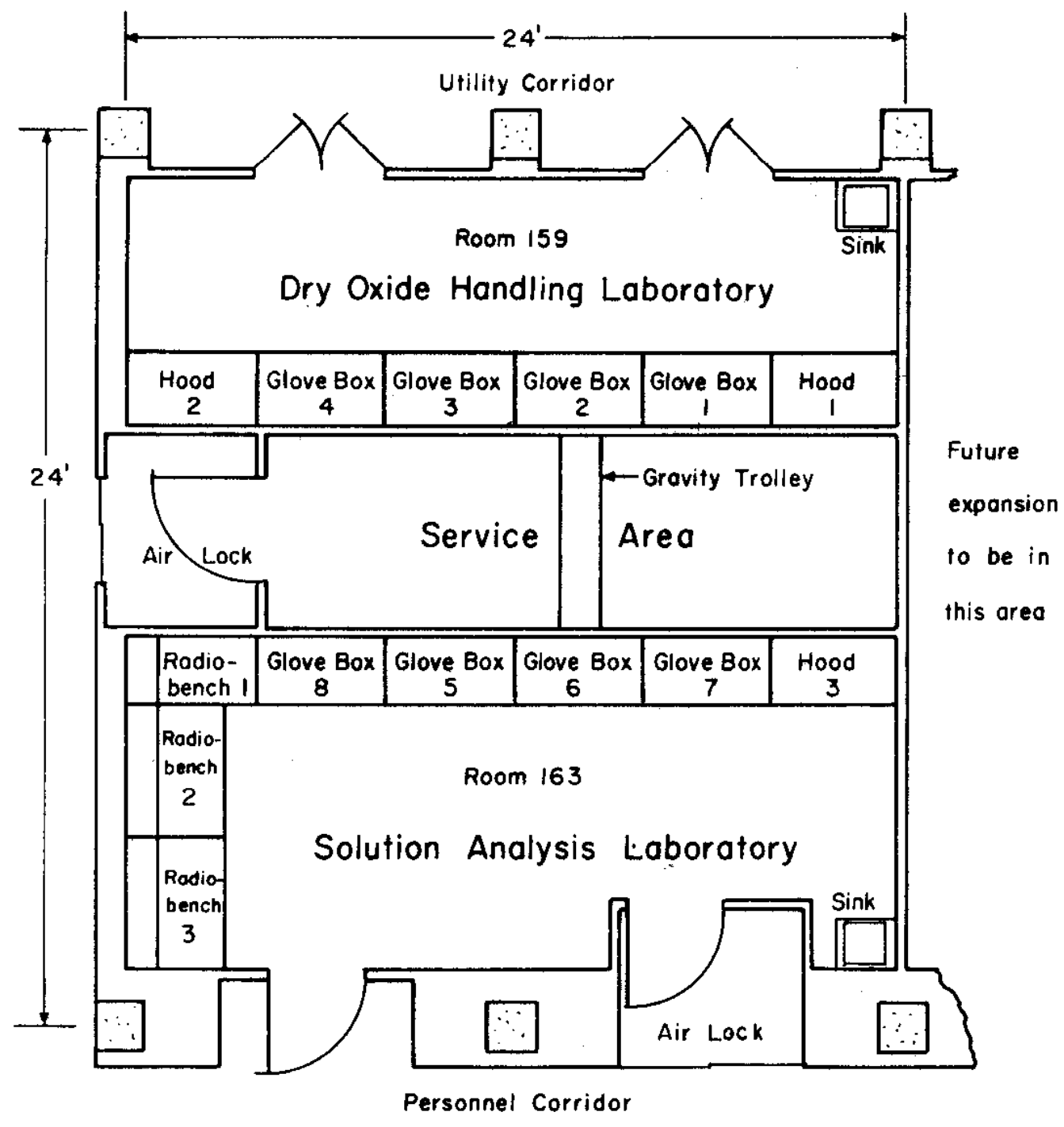

Figure 1. SRP High-Level Alpha Analytical Facility 


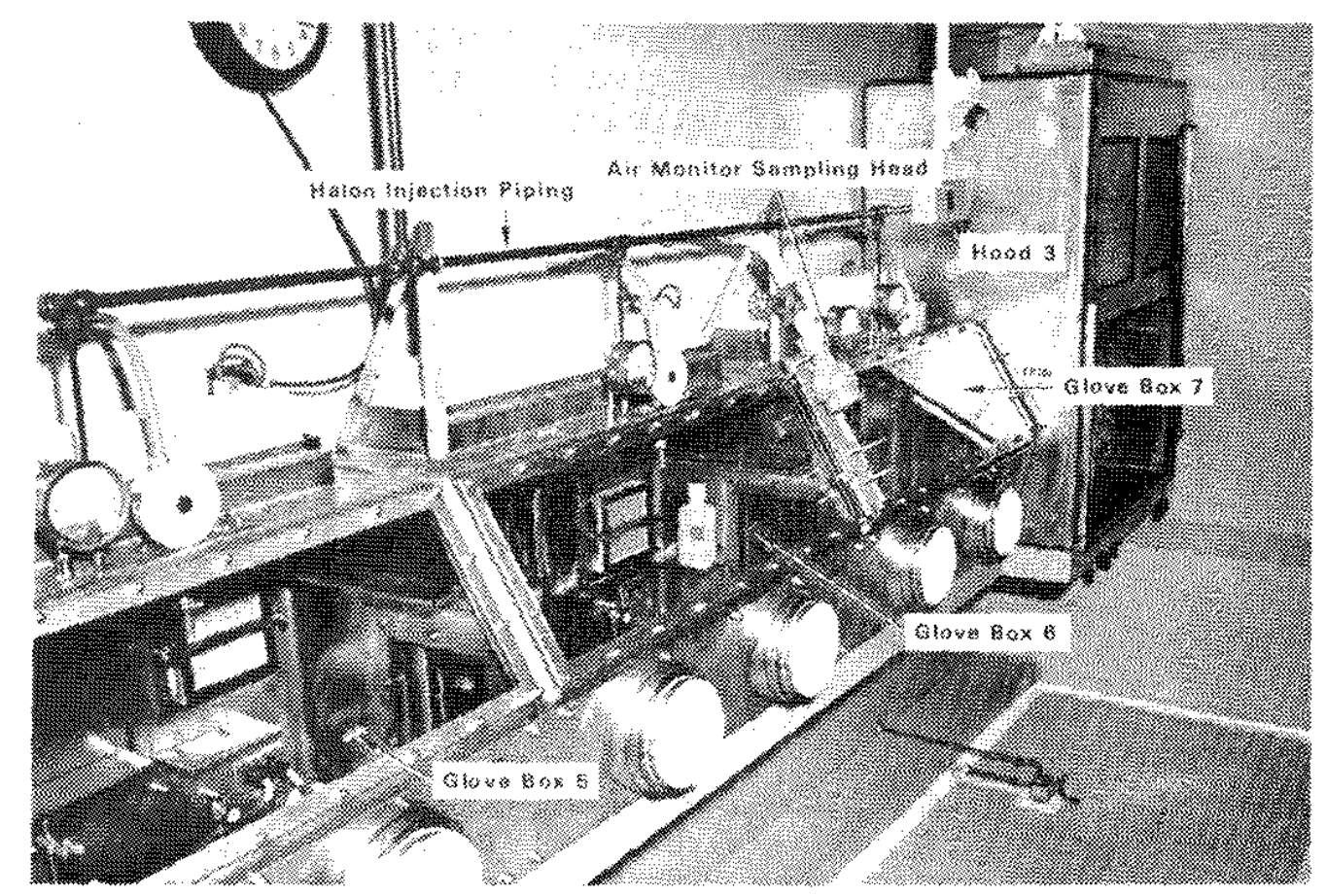

Fyue 2. Solution Mnalysis Laboratory (Coking konth)

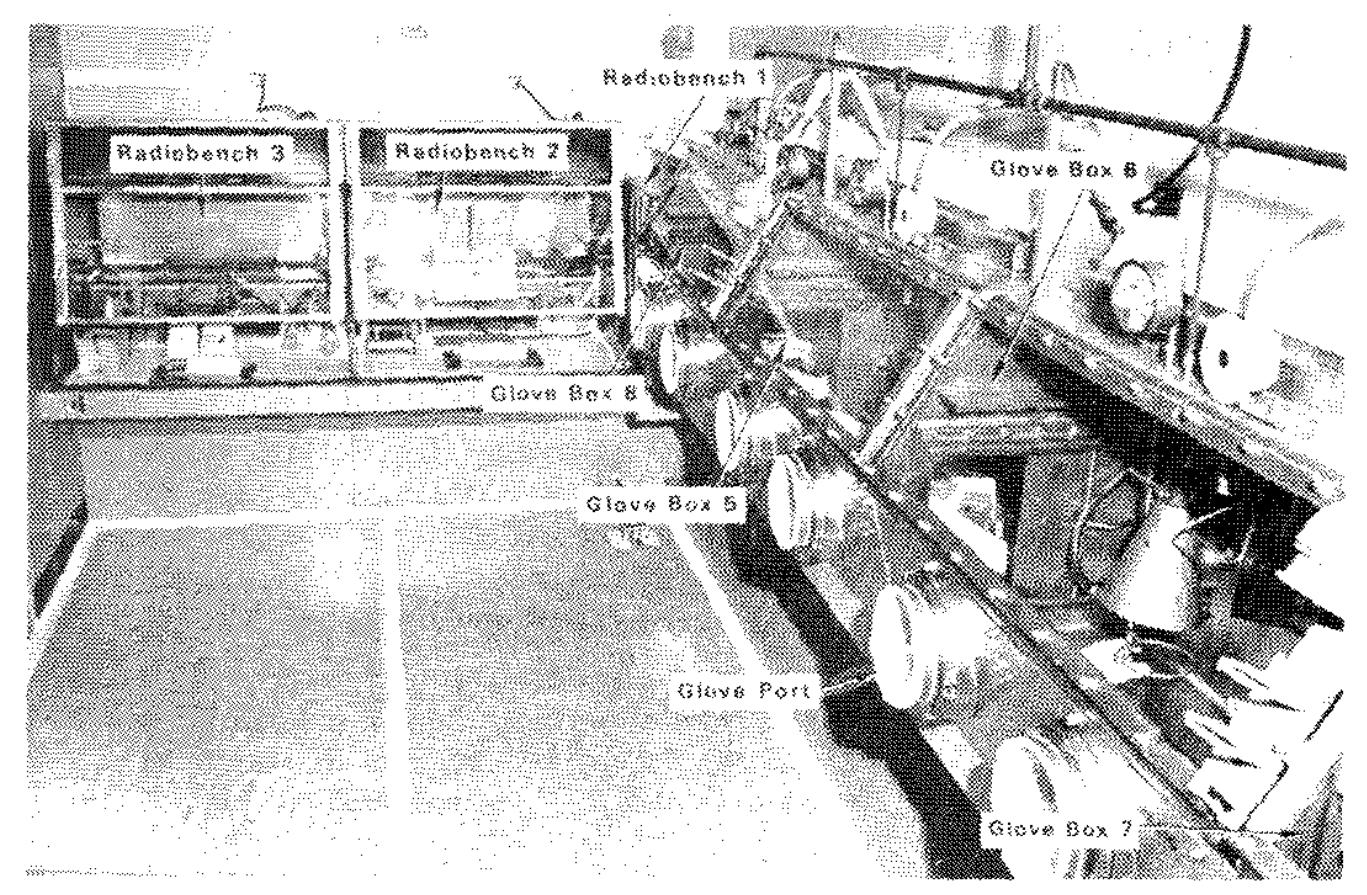

Figure 3. Solution halysis tabonatory (looking South) 
Shielding for the soft $X$-rays from ${ }^{238} \mathrm{Pu}$ oxide is provided by 1/8-in. stainless steel glove box walls with $1 / 16-i n$. lead added to the fronts and bottoms of the boxes. Lead-impregnated gloves are provided where justified by the quantities of oxide handled. Internal shielding is used for temporary storage of more than one gram of oxide.

Air is continuously monitored for alpha activity at breathing level at five stations in the operating areas and near the exhaust duct in the service area. Contamination levels are recorded, and alarms* warn operating personnel when activity reaches designated limits.

\section{SAMPLE ENTRY, TRANSFER, AND EXIT SYSTEM}

Samples are introduced to the Dry Oxide Handing Laboratory (Room 159) through an isolation box in Hood 1 (Figure 5). Analytical balances and other large items are transferred into or out of Glove Boxes 1 or 4 and via Hoods 1 and 2 after removal of bolt-on plates on which door and bag ports are mounted.

Removable plates at the rear of Glove Boxes 3 and 5 allow entry of items greater than the 10 in. $x 12-1 / 2$ in. glove box door opening (Figure 4). For these entries, the glove boxes can be ventilated at rates up to a maximum of $1000 \mathrm{cfm}$ by opening the transfer doors to the hoods.

Air flows continuously into the isolation box from the hood via an HEPA filter and then flows into Glove Box 1 through duststop filters. The air flow decreases contamination levels in the isolation box, and the filters avoid large decreases in glove box differential pressures during entry. Full exhaust capacity of the eight glove boxes ( $>200 \mathrm{cfm}$ ) may be used to avoid airborne contamination when transfers are made from glove box to hood.

Bag ports of 4-in. and 10-in. diameter for solid waste and recoverable oxide are provided. Bag-out operations are done in Hood 2 to control any possible spread of contamination. Liquid waste flows by gravity from stainless steel cup sinks in the containment units to tanks in the shielded areas below the room.

*W. J. Woodward. An Improved Air Monitor in a Standard Nuclear Instrument Module. USAEC Report DP-1260. E. I. du Pont de Nemours and Company, Savannah River Laboratory, Aiken, South Carolina (1971). 


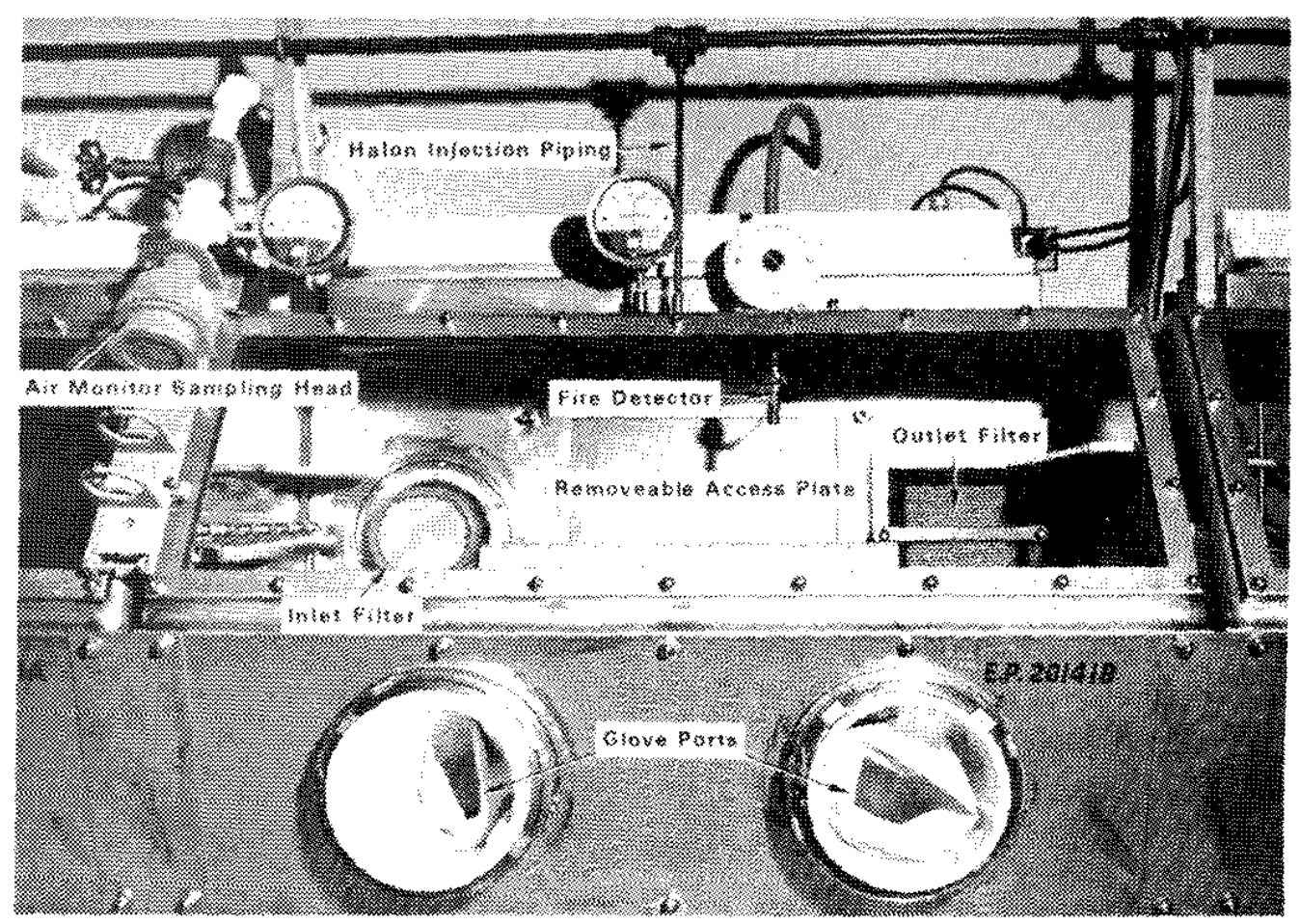

Figure 4. Typical Gove box

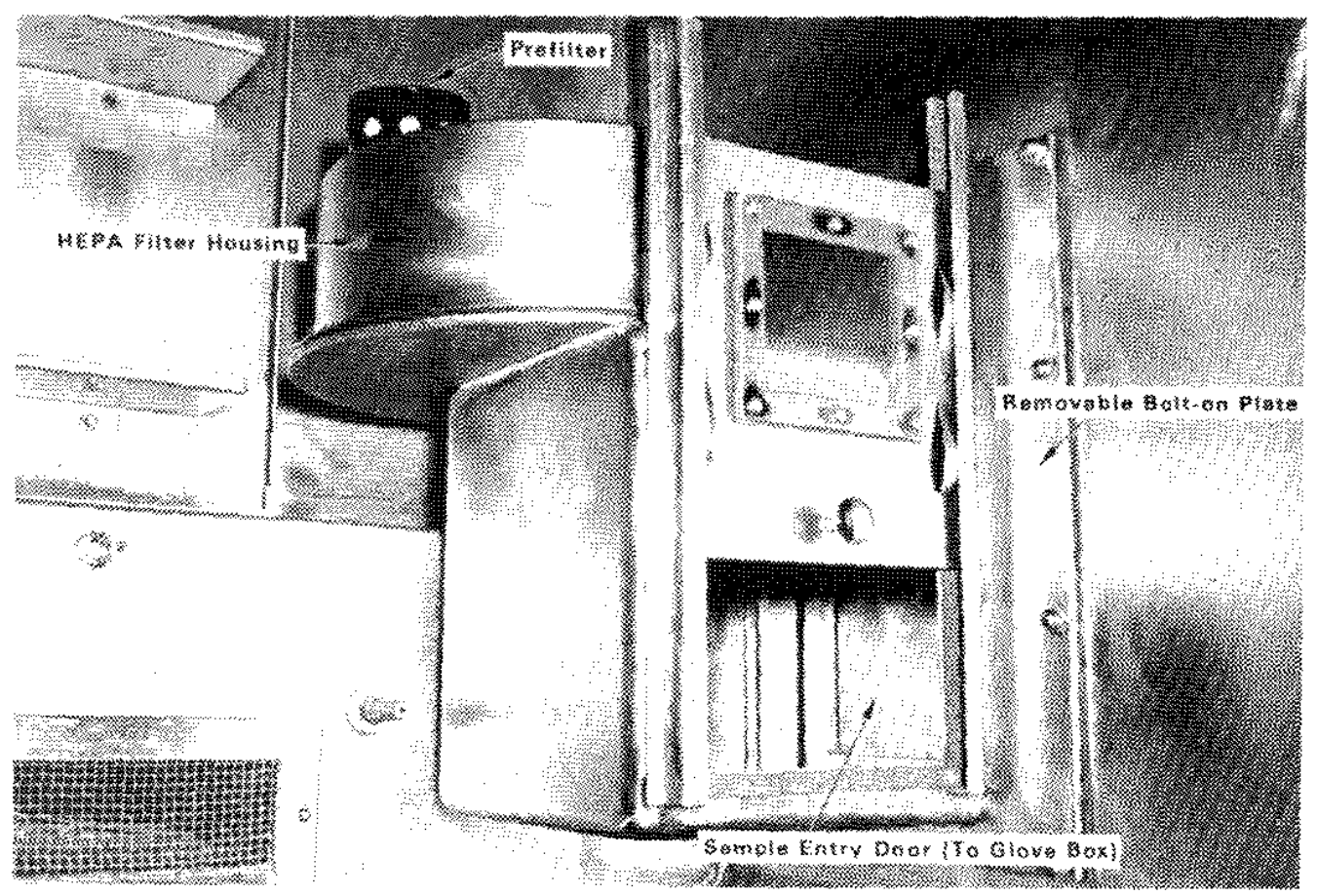

Figure 5. Isolation Box (Transfer Air Lock) - Hood 1 
Solutions of plutonium are transferred to the Solution Analysis Laboratory (Room 163) for wet chemical analysis by a gravitypowered trolley (Figure 6). The stainless stee1, ball-bearing trolley and track are removable for servicing or replacement. The trolley is more reliable and less costly than battery-powered carts used previously. Additional access to the solution analysis glove boxes in Room 163 is provided from Hood 3 and the radiobenches.

\section{CORROSION RESISTANCE}

The fiberglass containment units in the old facility were replaced by units constructed entirely of 1/8-in.-thick sheets of 304L stainless steel. 304L stainless steel was also chosen for all exhaust ducts and piping because of its proven corrosion resistance in the production facility and in labware used at SRP. Fire resistance, $X$-ray shielding, and structural strength were also factors in favor of its selection.

Corrosive atmospheres in the glove boxes are minimized by the large air flow (>15 cfm per box). Doors are installed between glove boxes to isolate corrosive fumes. To avoid corrosion of metal surfaces and etching of glass windows by hot $\mathrm{HNO}_{3}-\mathrm{HF}$. fumes during dissolution of $\mathrm{PuO}_{2}$, air flow is increased to approximately $30 \mathrm{cfm}$, and the acid fumes are directed to the exhaust system by a replaceable stainless steel canopy hood within the glove box (Figure 6).

\section{FIRE DETECTION AND SUPRESSION SYSTEM}

Detectors in each glove box (Figure 6) respond to a set temperature rise and automatically actuate a pressurized Halon 1301 injection system. Audible and visible alarms are transmitted to operating and Fire Department personne1.

Manual operation of the system from outside the operating area, but still within view of the glove boxes, is also provided. The system was tested by estinguishing an alcohol fire. The fire was extinguished in less than five seconds after detector response. The extinguishing agent was discharged for more than thirty seconds, and the pressure differential in the glove boxes was lowered from $0.5 \mathrm{in}$. to $0.2 \mathrm{in}$. $\left(\mathrm{H}_{2} \mathrm{O}\right)$. The two glove box trains are on separate detection and suppression systems, and each system has main and reserve Halon sources. Heaters are provided for testing the response of each detector periodically. 


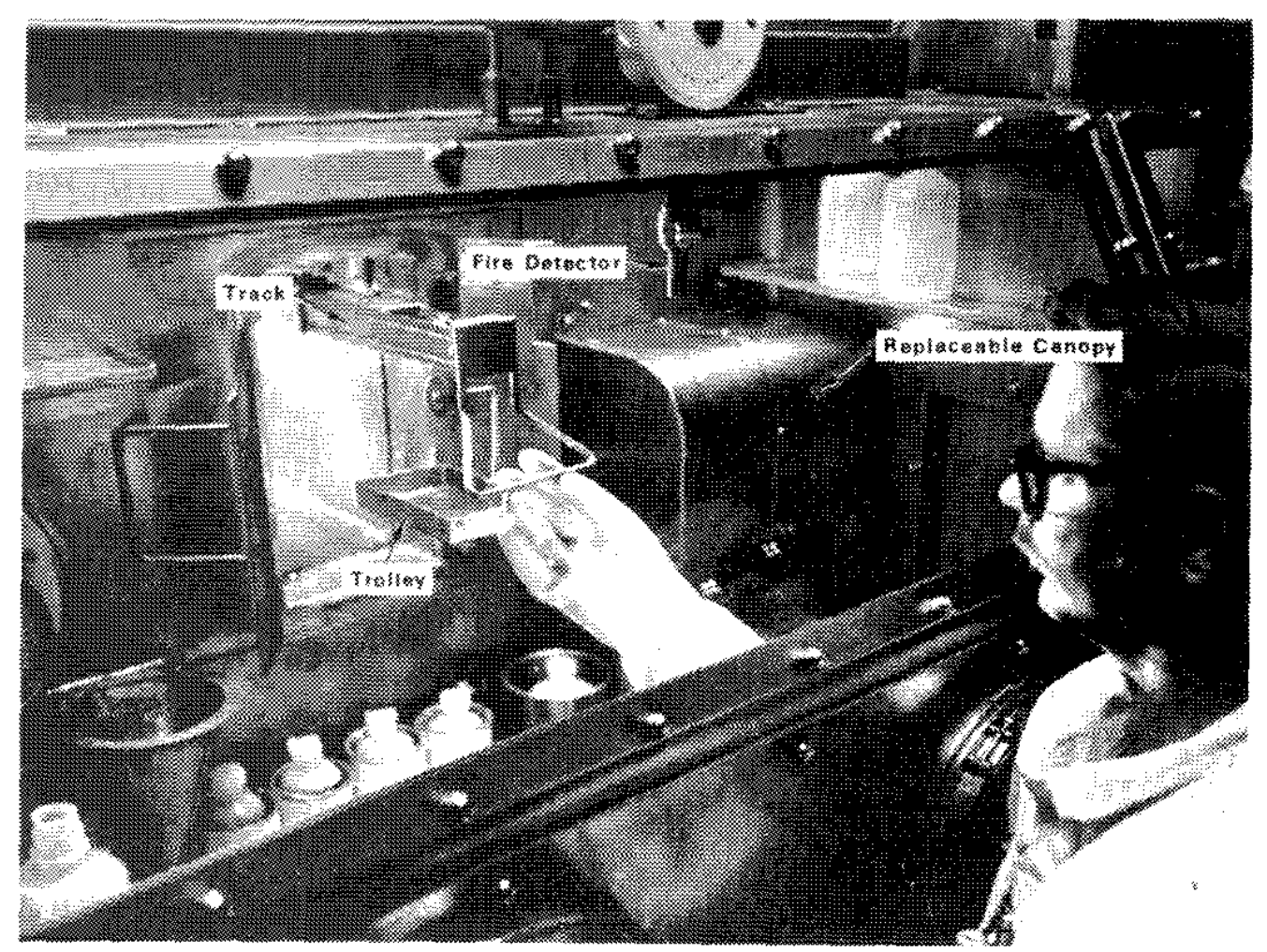

Foure 6. Cranty powered Trolley

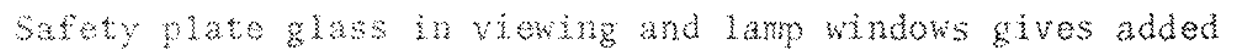
fare resistance, whe $\mathrm{w}_{2}$ does not adhere to th. Whe mesh in bedaed th the lam whow protects aganst shatering

\section{SEPVICE ACOEs}

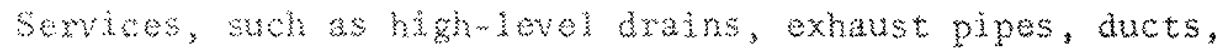

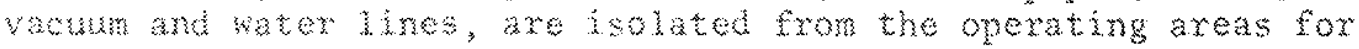

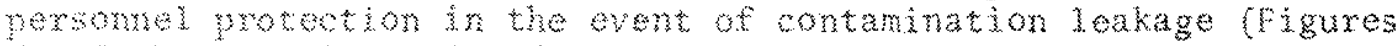

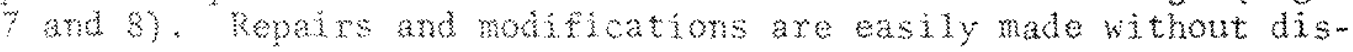

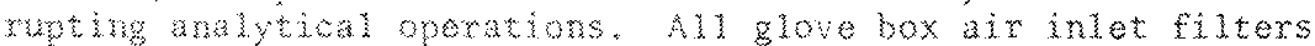

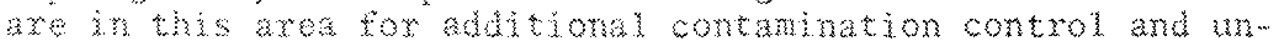

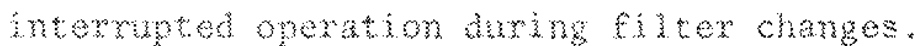

\section{$\cos$}

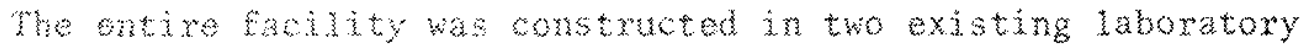
modules. construction regulrea one year, and the racility cost 3.50, 2500 . 


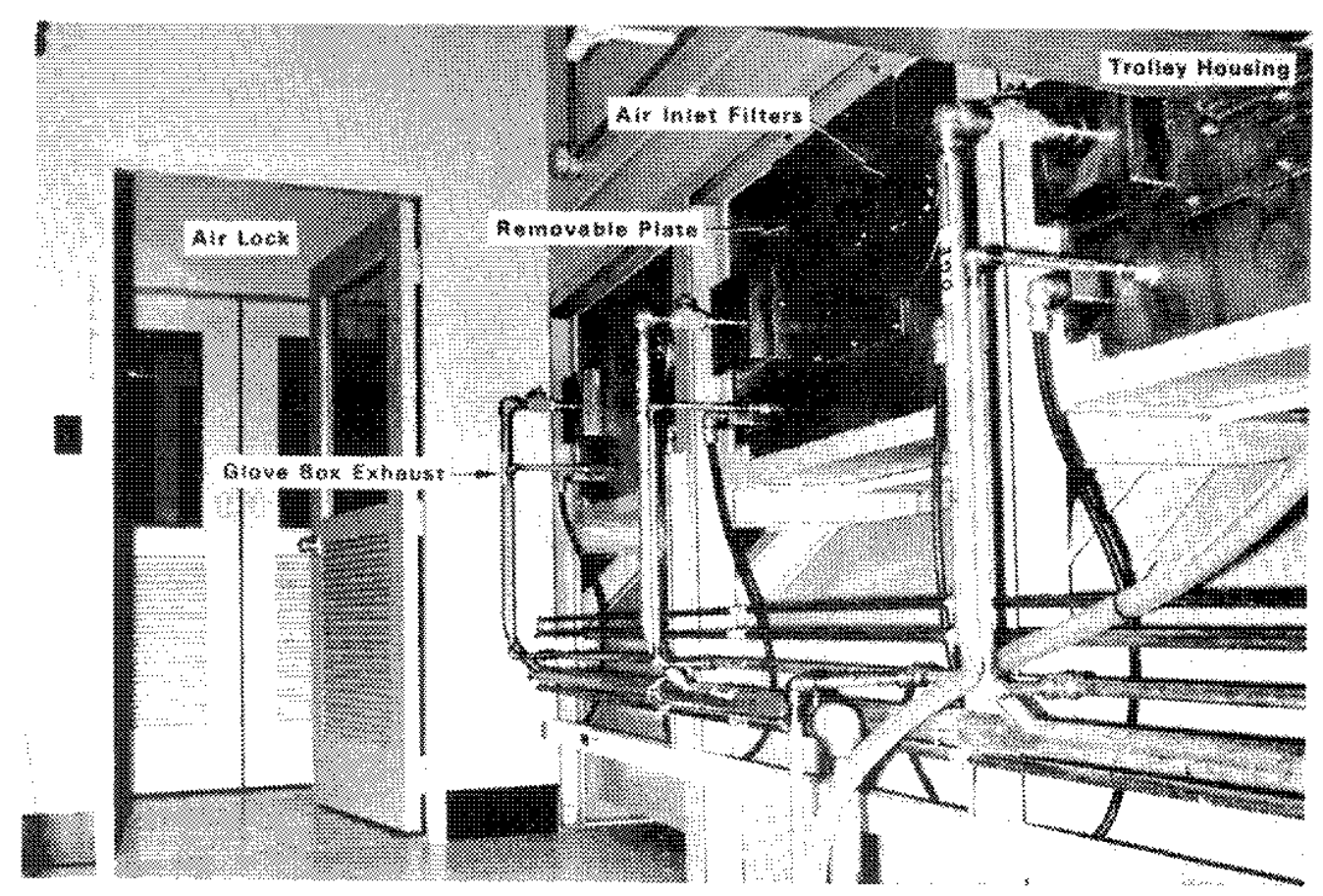

Figure 7. Service Area (lookino South)

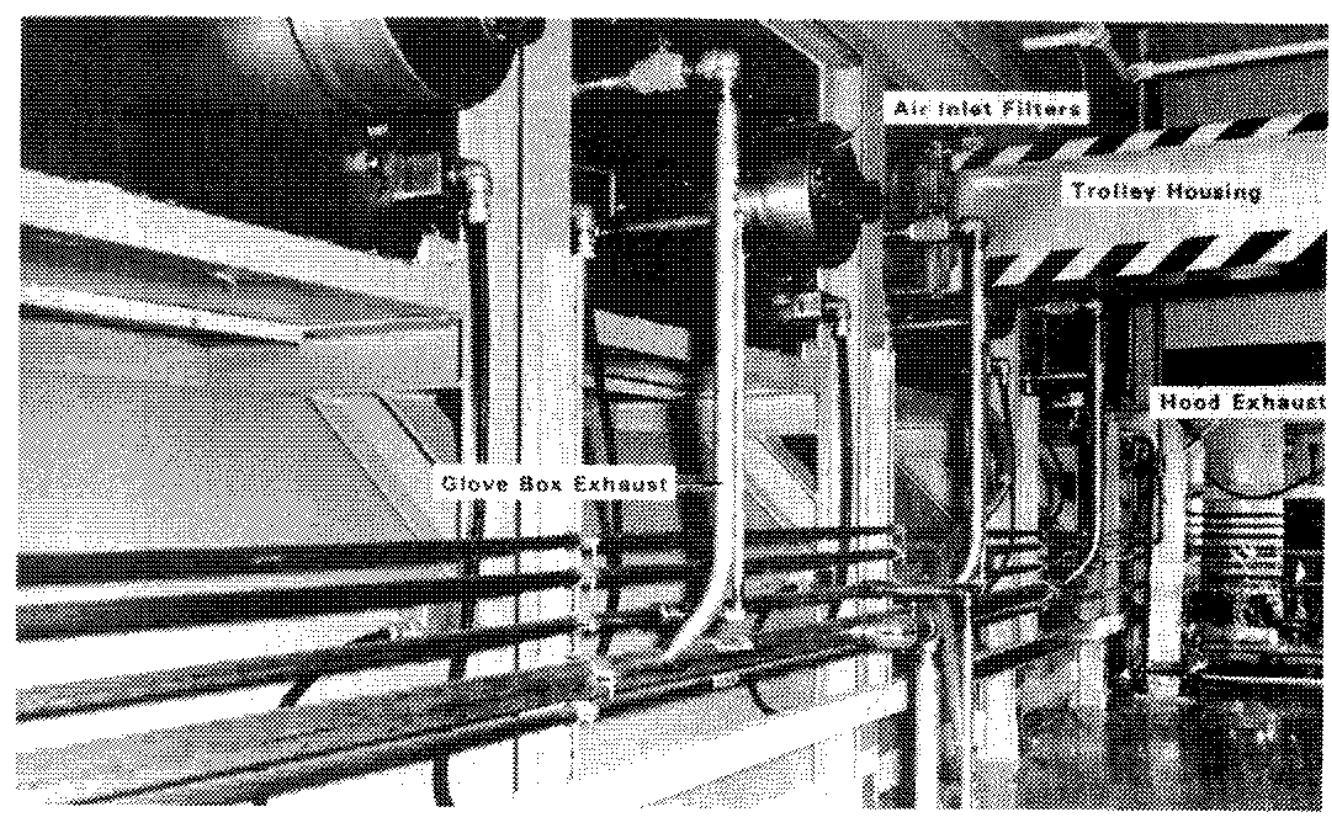

Figure o. Serytce area (Tookng Nonth) 